\title{
Developing socio-emotional intelligence in first year higher education students through one-to-one learning development tutorials
}

\author{
Camila Devis-Rozental \\ Bournemouth University, UK \\ Sue Eccles \\ Bournemouth University, UK \\ Marian Mayer \\ Bournemouth University, UK
}

\section{Abstract}

The relationship between socio-emotional intelligence and one-to-one Learning

Development (LD) support offered to HE students is relatively under-explored. Socioemotional attributes are often difficult to achieve solely within the classroom environment, although we know that engaging students in becoming more confident, resilient and selfaware can reduce their likelihood of withdrawal from their studies and improve personal achievement and success.

This study explored whether the support provided during one-to-one LD tutorials enhances areas of students' socio-emotional intelligence and, in turn, positively impacts on their overall academic and personal development. Through a focus group with students and analysing feedback given by students from one UK university in the south of England, the experiences and benefits of receiving faculty-based LD support were explored. The findings suggest that students accessing this type of support further develop aspects of socio-emotional intelligence. This assists students in their transition into and through Higher Education, can reduce withdrawal rates and significantly enhances the individual student's learning experience. We argue that supporting students in developing areas of socio-emotional intelligence such as motivation, self-awareness and confidence as part of the LD provision, empowers them to successfully complete their learning journey and benefit from the wider student experience. 
Keywords: Higher education; socio-emotional intelligence; learning development; retention; academic achievement; student experience.

\section{Introduction}

As universities strive to reduce student withdrawal from programmes and increase their achievement and success rates (Higher Education Academy, 2016), the provision of learning development can provide students with the skills and knowledge to support this. It can also enhance the student learning experience (Hilsdon, 2011). What is less understood is the relationship between one-to-one learning development support (LD) and the development of students' socio-emotional intelligence (Devis-Rozental, 2016). This is relevant since areas of socio-emotional intelligence such as resilience, motivation or selfawareness amongst others, have the potential to engage students with their studies so that they can succeed (Perera and DiGiacomo, 2015).

This article presents an overview of emotional intelligence and social intelligence, and a rationale for merging these two terms. Following this, socio-emotional intelligence within the context of education is presented. To set the context of this study, the support that the Learning Development (LD) team at a Faculty of Media and Communication in a UK institution provides, in order to develop academic skills, as well as facilitate strategies to develop socio-emotional intelligence will be discussed. Finally, design, development and findings from this small-scale study will be presented, with conclusions about how these may impact on similar provision across the sector.

\section{From social and emotional intelligence to socio-emotional intelligence}

Socio-emotional intelligence (Castejon et al., 2008; Devis-Rozental et al., 2014; DevisRozental, 2016) is the ability to understand, manage and engage both our emotions and our social interactions in an appropriate manner, for the right purpose and with the right person (Bar-On, 2005; Goleman, 1996, 2007; Devis-Rozental et al., 2014). Its main aim is to enrich our experiences, improve our relationships and enhance our overall wellbeing (Devis-Rozental, 2016). Socio-emotional intelligence has been traditionally studied as a 
dual premise, where emotional and social intelligence are defined separately but arguably these are intertwined.

Salovey and Mayer defined emotional intelligence as:

The ability to monitor one's own and other's feelings and emotions, to discriminate among them and to use this information to guide one's thinking and actions. (Salovey and Mayer, 1990, p.189)

Goleman (1996) explains that emotional quotient-intelligence (EQ) is an individual's ability to understand and manage their own emotions and relationships, as well as those of others.

Interestingly Thorndike (1920) posited the notion of social quotient-intelligence (SQ); the ability to understand and manage other people, Cantor and Kihlstrom (1987) later redefined SQ as a personal understanding of the social world. More recently, this notion of $\mathrm{SQ}$ as one-dimensional and generalised has been challenged, for example, by Gardner (2000), who introduced the concept of multiple intelligences, positioning SQ as two types of intelligence: interpersonal, the ability to read other people's social cues; and intrapersonal, the ability to understand our own emotions.

Today, both $E Q$ and $S Q$ are seen, as intrinsically linked (Bar-On, 2005, Castejon et al., 2008). For instance, Goleman asserts that 'all emotions are social' (2007, p.83), as individuals are sharing what they are feeling for a common purpose and those emotions might be triggered by the social environment, or an external influence. Concurring with the idea presented above by Gardner (2000) and Goleman (2007) that social and emotional intelligence intertwine and it may be quite difficult to distinguish between them, Bar-On (2005) provides a further definition of emotional-social intelligence. According to him it is a:

Cross section of interrelated emotional and social competencies, skills, and facilitators that determine how effectively people understand and express themselves, understand others, and relate with them, and cope with daily demands. (Bar-On, 2005, p.14) 
Consequently, it can be argued that social and emotional intelligence should be integrated as they are both essential to the understanding of each other. Acknowledging that, Jennings and Greenberg (2009) use what they see as the wide construct of social emotional learning (SEL), to discuss these aspects in relation to teaching and learning within the classroom. Experience affects how people behave, especially as the way in which people act, reflect, react or re-enact changes is based on personal experiences (Bandura, 1977; Lankshear and Knobel, 2011; Vygotsky, 1978). The same could be true for socio-emotional intelligence, and whilst personality characteristics, which are innate, should to be taken into account, these are not fixed and can be developed or managed with appropriate knowledge and support - for instance whilst in education.

The importance of socio-emotional intelligence in the classroom has been widely accepted (Jennings and Greenberg, 2009). In the UK, school age children have initiatives such as social and emotional aspects of learning (SEAL) (Humphrey et al., 2010). To Jennings and Greenberg (2009) social and emotional competences (SEC) are central to classroom outcomes. Consequently, supporting students to develop these capabilities adds to their experience (Davis, 2010). Dryden and Vos (1994) assert that education must consider personal and emotional development as these are critical to effective learning. Whilst studying the best educational practices, they found that emotional development was at the centre of their programmes.

\section{Learning development in higher education}

According to Hilsdon (2011):

Learning development is a complex set of multi-disciplinary and cross-disciplinary academic roles and functions involving teaching, tutoring, research and the design and production of learning materials. (Hilsdon, 2011, p.14)

This study is situated within one faculty in a university in the south of England. The provision may be similar to that offered elsewhere across the sector and is based around a team of four research active academics, with a background in education and pedagogical approaches, who support students in a variety of ways to develop their learning and 
academic skills as well as transitions (Foster et al., 2011). Within the team, all of these functions noted by Hilsdon (2011) are undertaken, although the main focus is on one-toone tutorials where students can be supported holistically. In 2015-2016, over four hundred students received LD tutorials, which covered not only discussion around their learning development needs, but also other elements of their overall university experience that may have a positive or negative impact on their learning and academic engagement. Matters et al. (2004) suggest such support requires experienced staff and appropriate training for those working with students and each member of the team is knowledgeable and skilled in all areas of learning development, as well as being familiar with the subject disciplines (and conventions) within the Faculty.

Latsome (2013) argues that lecturers should, as part of their teaching, promote and encourage development of attributes like acceptance, empathy and respect for successful social and intercultural interactions. However, we argue that, where such support is taken out of the lecture theatre or classroom but still provided within the same academic context as the students' programme, relevant and tailored opportunities can be provided to develop students' socio-emotional intelligence, whilst enhancing their learning and academic ability. The rationale for this is the simple premise that subject-specific academics may not have the time or, in some cases, the expertise to support students to develop these types of skills.

Seal et al. (2011) and Qualter et al. (2009) argued that integrated teaching programmes can provide the level of support and opportunities for students to develop both their learning ability and their socio-emotional intelligence. This is further supported by Low et al. (2004), who collated findings from their main studies and research projects related to emotional intelligence. They were able to confirm:

..the importance and value of emotional intelligence and personal skills to college and career success. (Low et al., 2004, p.2)

They established a programme to support first year HE students to develop their emotional intelligence in order to aid their success. Their programme is delivered through formal classroom interventions. 
The site of this study reflects such a programme by also delivering lectures and workshops to all students, as well as one-to-one LD tutorials. These tutorials are student-initiated and -led, specifically responding to individual students' needs. This differentiated approach provides an opportunity to get to know and understand the student in a holistic way. They often seek an individual tutorial because of specific personal issues that are 'blocking' their learning and through understanding and addressing these, a scaffold or structure for their learning and overall experience can be developed - ultimately making them more likely to achieve, succeed and flourish.

At the same time, by building positive relationships, students develop a sense of belonging whilst gaining knowledge, which in turn will support them in becoming more confident, independent learners. This bespoke LD support carried out by academics with an in-depth knowledge of pedagogical approaches, provides individualised tutorials taking into account each student's academic, social and emotional needs. This aligns with Arambewela and Maringe's (2012) idea of the importance of providing continuous support, including pastoral support, from the outset. This, Arambewela and Maringe (2012, p.16) argue, helps towards 'integrating students so that they feel they belong to the programme and are part of a student body within the wider university' enhancing their overall experience.

For first year students, either at undergraduate or postgraduate level, making transitions from school, work or other commitments, to university (Parker and Duffy 2005), and coping with a range of issues as diverse as homesickness, adapting to the academic conventions or experiencing a culture clash (Davis, 2010), can be problematic. Qualter et al. (2009) noted that for some students this creates tensions which, in the absence of appropriate support, lead to negative experiences and eventual withdrawal from their course. They have evidenced that a programme targeted at undergraduate students to increase their socio-emotional intelligence, could 'increase their likelihood of staying on at university' (Qualter et al., 2009, p.14).

Fayombo (2012) found that there is a relationship between emotional intelligence and academic achievement. Furthermore, a national study by the American College Test organisation (ACT), found that the main reason first year students leave is not their 'academic ability' but because of 'personal factors' (Low et al., cited ACT, 2004, p.5). Therefore, by providing the one-to-one bespoke support it is possible to support those 
students who might be struggling, to ensure they are able to continue with their studies as they gain confidence and resilience and, by gaining new-found knowledge, become more motivated.

\section{Research aim and methodology}

The aim of this study was to explore how the existing one-to-one LD support offered to students helps in developing their socio-emotional intelligence, gaining confidence and fully engaging with all the academic and related learning opportunities.

Whilst institutional data can provide the academic progress of students, it does not provide the detail of how the students progressed, nor specific interventions which would support (or otherwise) such progress. For this reason, this small-scale study adopted an interpretivist approach (Lincoln and Guba, 1985; Hudson and Ozanne, 1988; Black, 2006), as reality is subjective and depends on individual experiences and how these are perceived. This would allow students' views and reflections to be captured through an informal focus group (Stewart et al., 2007), and the recording and analysis of all spontaneous verbal feedback and written comments given by students via emails.

Aligned with the discussions around socio-emotional intelligence, a series of themes were identified, based on the literature (see Table 1 below) and these provided a framework both for the focus group discussion and subsequent analysis.

Table 1. Key elements of socio-emotional intelligence.

\begin{tabular}{|c|l|}
\hline Term & Theoretical frameworks informing use of the term \\
\hline Motivation & - Goleman (1996). \\
& - Self-Motivation; self-awareness (Bar-On, 2005). \\
& - Set and achieve positive goals (Payton et al., 2008). \\
\hline Resilience & - Self-regulation (Goleman, 1996). \\
& - Recognise and manage emotions (Payton et al., 2008). \\
& - Emotional perception and identification (Salovey and \\
\hline Empathy & - Mayer, 1990). \\
\hline & - Eoleman (1996); Albrecht (2006). \\
& - Demonsthic accuracy; primal empathy (Goleman, 2007). \\
\hline
\end{tabular}




\begin{tabular}{|c|c|}
\hline & 2008; DFES, 2005a; DFES, 2005b). \\
\hline $\begin{array}{l}\text { Social } \\
\text { engagement }\end{array}$ & $\begin{array}{l}\text { - Social skills (Goleman, 1996). } \\
\text { - Attunement, social cognition, synchrony, influence } \\
\text { (Goleman, 2007). } \\
\text { - Situational awareness; clarity (Albrecht, 2006). } \\
\text { - Demonstrating care and concern for others; } \\
\text { establish and maintain positive relationships; handle } \\
\text { interpersonal situations effectively (Payton et al., 2008; } \\
\text { DFES, 2005a; DFES, 2005b). } \\
\text { - Social awareness and interpersonal relationships; self- } \\
\text { expression (Bar-On, 2005). }\end{array}$ \\
\hline $\begin{array}{l}\text { Confidence } \\
\text { \& self- } \\
\text { esteem }\end{array}$ & $\begin{array}{l}\text { - Emotional understanding (Salovey and Mayer, 1990). } \\
\text { - Self-awareness (Goleman, 1996). } \\
\text { - Self-presentation (Goleman, 2007). } \\
\text { - Authenticity; Presence (Albrecht, 2006). } \\
\text { - Make responsible decisions (Payton et al., 2008). }\end{array}$ \\
\hline Patience & $\begin{array}{l}\text { - Emotional management (Salovey and Mayer, 1990). } \\
\text { - Emotional management and regulation (Bar-On, 2005). } \\
\text { - Self-regulation (Goleman, 1996). } \\
\text { - Recognise and manage emotions (Payton et al., 2008; } \\
\text { DFES, 2005a; DFES, 2005b). } \\
\text { - Self-awareness (Bar-On, 2005). }\end{array}$ \\
\hline
\end{tabular}

\section{Research methods}

In addressing the aim of this study, two broad methods were used - the first was to analyse data that students who had received LD support had given either verbally or sent via email. These comments and emails were student initiated, and were written giving feedback regarding the support students had received from our team. In order to follow ethical protocol and once ethical approval from our institution was gained, permission was sought from the students to use their feedback for research purposes. These emails provided an overview of some of the key issues.

This was then followed by a focus group consisting of four undergraduate students, in their second and third year, to explore some of these issues in more detail. The rationale for engaging second and third year students was that they would have had time to reflect on the type of support received, and how it had impacted on their socio-emotional intelligence. All the students who had received one-to-one support were approached to take part in the study. Six students showed an interest and of those, four were able to participate. These four students were females between the ages of 20 and 50 completing 
a higher education qualification. They had all received one-to-one support to develop their academic skills during their first academic year.

A focus group was selected in preference to individual interviews because it presented an opportunity to observe interactions, to gain a better understanding through:

...listening to the participants' discussions, challenges and contradictions.

(Liamputtong, 2011, p.32)

The aim was to understand these students' experiences of and reflections on the LD support they had received. At the same time, specific areas of socio-emotional intelligence were explored to understand how students felt these impacted on their university experience.

\section{Ethical considerations}

According to the British Educational Research Association (BERA, 2011, p. 4) "all educational research should be conducted within an ethical respect for:

- "The person" - participants were given time to reflect and contribute, respecting each individual's ideologies, culture, principles and rights. Anonymity and confidentiality where adhered to throughout the study.

- "Knowledge" - we aimed to present these findings by interpreting them using robust methods so that, whilst developing a new gained insight we represented the students' views preserving that knowledge.

- "Democratic values" - fairness, transparency and choice have been integral to this study. We encouraged students to explore their views whilst respecting their privacy. We accounted for quality and diversity issues and treated everyone with 'unconditional positive regard' so they felt valued and able to express freely. Participants were offered the opportunity to read the transcription to establish if there was anything else to contribute, and for them to know that their contribution would be voiced effectively. 
- "The quality of educational research" - we maintained a systematic approach to carrying out qualitative research. Ethical procedures were adhered to, taking into consideration ethics guidelines. Permission was sought to consider participants' confidentiality, privacy and anonymity (Bell, 2010; Atkins and Wallace, 2012; Holloway and Brown, 2012). We ensured that all participants were clear about their involvement in the project.

- "Academic freedom" was and is sought throughout each stage, by expressing freely and independently ideas and findings, whilst maintaining professionalism, with the aim to create new meaningful knowledge to Learning Development.

Transparency and reflexivity were applied throughout this research project. Participants were aware of their right to change their mind and leave the project if they wished to do so. None of those involved in the project withdrew.

Institutional ethical approval was granted - aside from the standard issues of confidentiality, right to withdraw, use of the information mentioned above, the power imbalance between researcher (academic) and participant (student) was acknowledged. Students who had given feedback were reassured that their names would be changed before transcribing their comments. Students who took part in the focus group were provided with an information sheet, which included details of staff outside of the project to whom they could turn if they had any concerns or questions. All students were reminded that their input would not impact in any way on the learning development support they received, or any other part of their academic studies.

After completing the ethics forms, students taking part in the focus group were briefed and reminded of both the ethics underpinning this study and that their names would be changed prior to analysing the transcription. They were then provided with a definition of socio-emotional intelligence to ensure their understanding of the study - as presented above - and each term was discussed sequentially. There were also discussions around their experiences of receiving LD support within the broader context of their university life. The focus group was audio-recorded (with consent) for later transcription. 


\section{Data analysis}

The data from both the written feedback and the focus group were analysed thematically by one member of our team and collaboratively discussed to confirm the findings (ButlerKisber, 2010). Using the characteristics listed in Table 1, a generic interpretivist qualitative research (Black 2006) was carried out. Data were scrutinised for 'themes, categories, or patterns' (Johnson 2005, p. 63). In addition, overarching 'stories' of these students' experiences were noted, providing a rich picture of some of their perceptions of and reflections on transitioning into and through university.

\section{Findings and discussion}

The purpose of this paper was to find out if one-to-one learning development tutorials had an effect in supporting the development of socio-emotional intelligence. The written feedback from students showed that they had used terminology traditionally related to socio-emotional intelligence with words such as confidence and motivation. They alluded to ideas linked to self-awareness, resilience, social cognition and others which have been explored by theorists when referring to socio-emotional intelligence (Albrecht, 2006; Goleman, 1996, 2007; Salovey and Mayer, 1990). Students talked about 'feeling better' 'feeling more confident' and one stated:

I found your comments very educative and encouraging. (Alan)

Qualitative formative findings and conclusions based on students' written and verbal recorded feedback acknowledged the value of personalised support. For instance, this post-graduate international student stated:

Thank you very much for your professional input. It does really help; I had some doubts before which are now clarified...I feel more confident. (Stefan)

With our support, Stefan was able to complete his assignment and feel confident about his capabilities. Concurring with this, Marco noted: 
Without your academic and psychological support, I would have left my course...there should be one of you in every university course.

Marco had approached our team as he had been failing his programme and was feeling anxious due to finding the transition to university quite hard (Parker and Duffy, 2005). He acknowledged how, after receiving our support, he felt 'psychologically' better and more confident in his abilities. In this case, his emotional wellbeing, resilience and confidence improved and he was able to continue his studies successfully. All these areas are well documented in the literature as being aspects of socio-emotional intelligence (Albrecht, 2006; Devis-Rozental et. al, 2014, 2016). Daniel, a postgraduate student who also refers to our support as 'psychological' wrote:

I couldn't imagine what I would do without your psychological support! Thank you one more time!

In this specific instance, we worked to improve Daniel's academic confidence and selfesteem so he was able to complete his studies successfully. After Daniel graduated he emailed:

I am so happy to inform you that I have been awarded the MA with merit... Needless to say how grateful I am, and how I feel so happy about our meetings! You really helped me so much, me and many, many other students.

To Daniel, our support had been integral to his success. This finding concurs with Low et al. (2004) and Fayombo's (2012) notion regarding the importance of emotional intelligence for academic success. We provided this student with a safe space in which he could be himself and where he could learn these new academic skills by trying them without a fear of failure. He went on to successfully complete his Master's programme. Qualter et al. (2009) discuss that without appropriate support students may eventually withdraw, and in this particular case that would have happened.

Similarly, Linda, a first year undergraduate student said: 
I can't explain how much it (our tutorial) helped me to calm down and feel a bit more relaxed.

We were able to give Linda the space and time to work on her anxiety whilst still developing her academic skills. By incorporating positive psychology techniques and a safe environment in which she could work productively, Linda's wellbeing was enhanced. As discussed in the literature review, we know that our learning development tutorials, which incorporate pastoral support, are in line with Arambewela and Maringe's (2012) view of how this type of provision can enhance the student experience. Indeed, all the students who gave feedback expressed how much the one-to-one tutorials had been a positive experience.

The focus group included four students, Dana and Stella in the second year of their degree and Alli and Lucy in their third year. They had all received personalised support in the form of one-to-one tutorials during their first year. Their responses highlighted that personalised provision seems to also support the development of socio-emotional intelligence. They discussed and agreed that having the support, space and especially the time to develop their socio-emotional intelligence through LD tutorials, had a positive impact on their learning and academic journey. Conversely, Seal et al. (2011) and Low et al. (2004) argued that integrated teaching programmes could provide such support. However, given the emotionally charged environment in which such tutorials may take place, especially if students are upset, we argue that delivering this type of support on a more personal oneto-one can be much more effective.

These participants placed great value on aspects of socio-emotional intelligence such as 'confidence', 'resilience' and 'motivation' (Salovey and Mayer, 1990; Goleman, 1996, 2007; Payton et al., 2008 amongst many others), and acknowledged that without appropriate support, these may not be developed as effectively, at least whilst at university. Alli for example, continuously referred to her confidence following the one-to-one support, and when discussing SEI she stated that having someone:

...who you can go to and talk about ... how you are going to approach your work... [or] that I am struggling with my essay or I'm struggling with work or I'm struggling 
with time management...gives you that confidence to be able to graduate yourself because I think a lot of it is not having the belief in yourself.

It seems that this personalised type of tutorial is necessary to support students in developing some areas of socio-emotional intelligence.

Based upon words such as 'encouragement' or 'engagement' (all areas of socio-emotional intelligence), students identified how our support had made a difference to their learning journey as well as their personal development. As is evident from the quotes above, they reported feeling more relaxed, calm and able to stay in their programme. This is further validated as they gained and reinforced positive relationships, both with the academic staff and other students.

\section{Implications for practice}

It would appear that the intervention of LD tutorials, supports students in becoming selfdirected and more confident learners, able to fully engage with their university experience. This intervention provides students with the academic skills and knowledge to support their learning and also the time to develop a rapport and the space to discover the barriers that impede their learning. Since most of the time these barriers relate to personal circumstances which in turn influence areas such as motivation, engagement or confidence, our support enables students to develop their socio-emotional attributes. This has an effect on their final grades, work prospects and long-term improvement and/or maintenance of the educational establishment's national and global reputation. Most importantly it influences their own socio-emotional intelligence as they gain skills, motivation and the confidence and belief to be self-reliant and independent.

Our students expressed the opinion that the support they received in their first year, from our LD team, helped them recognise and respond to feedback, plan for and meet deadlines, work in groups and understand the requirements and conventions of academic work more effectively. Students reported a more 'rounded' and positive learning experience, which they felt equipped them to achieve in, and enjoy their academic studies, whilst also having the confidence to engage in wider university and life opportunities. 
Going forward, one-to-one tutorials that incorporate positive learning strategies such as praise, constructive feedback and opportunities for self-efficacy and self-awareness, will continue to be available to students, informed by research-evidenced practice.

\section{Conclusion}

The findings from this small-scale study suggest that faculty-based LD teams - who are experienced academics with a background and in depth knowledge of pedagogical approaches as well as an understanding of how to support students with pastoral issues, but not necessarily subject specialists - can have a positive effect on aspects of students' socio-emotional intelligence, by providing bespoke support within a holistic context. Our support sits outside the individual programmes but within the faculty, providing greater synergy between this form of support and the students' own programmes of study. It is offered face-to-face by academics who, whilst not subject specialists, are subject knowledgeable and expert pedagogues. Findings from our research are encouraging, suggesting that students do feel settled and have a sense of belonging, when developing positive relationships with our team. What is more, with our intervention and support, students do succeed where otherwise, they may have failed.

\section{References}

Albrecht, K. (2006) Social intelligence: the new science of success. San Francisco: Jossey-Bass.

Arambewela, R. and Maringe, F. (2012) 'Mind the gap: staff and postgraduate perceptions of student experience in higher education', Higher Education Review, 44(2), pp. 6384.

Atkins, L. and Wallace, S. (2012) Qualitative research in education. London: Sage Publications Ltd. 
Bandura, A. (1977) Social learning theory. Englewood Cliffs, NJ: Prentice Hall.

Bar-On, R. (2006) 'The Bar-On model of emotional-social intelligence (ESI)', Psicothema, 18(1), pp. 13-25.

Bell, J. (2010) Doing your research project: a guide for first-time researchers in education, health and social science. $5^{\text {th }}$ edn. Berkshire: Open University Press.

Black, I. (2006) 'The presentation of interpretivist research', Qualitative Market Research: An International Journal, 9(4), pp. 319- 324. https://doi.org/10.1108/13522750610689069

BERA - British Educational Research Association (2011) Ethical guidelines for educational research. London: BERA. Available at: https://www.bera.ac.uk/wpcontent/uploads/2014/02/BERA-Ethical-Guidelines2011.pdf?noredirect=1 (Accessed: 20 October 2017).

Butler-Kisber, L. (2010) Qualitative inquiry: thematic, narrative and arts-informed perspectives. London: Sage Publications Ltd.

Cantor, N. and Kihlstrom, J. F. (1987) Personality and social intelligence. Englewood Cliffs, NJ: Prentice-Hall.

Castejon, J. L., Cantero, M. P. and Perez, N. (2008) 'Differences in the socio-emotional competency profile in university students from different disciplinary areas', Electronic Journal of Research in Educational Psychology, 6(2), pp. 339362.

Davis, J. (2010) The first generation student experience: implications for campus practice, and strategies for improving persistence and success. Virginia: Stylus Publishing.

DFES - Department for Education and Skills (2005a) Excellence and enjoyment: social and emotional aspects of learning. Norwich: Crown copyright. Available at: http://webarchive.nationalarchives.gov.uk/20110809172506/http://wsassets.s3.ama 
zonaws.com/ws/nso/pdf/0848b5e22bb2703a07a1e58567bce886.pdf (Accessed: 20 October 2017).

DFES - Department for Education and Skills (2005b) Social and emotional aspects of learning (SEAL): Improving behaviour, improving learning. Norwich: Crown copyright. Available at:

http://webarchive.nationalarchives.gov.uk/20110812101121/http://nsonline.org.uk/n ode/87009 (Accessed: 20 October 2017).

Devis-Rozental, C. (2016) 'Developing socio-emotional intelligence in early years educators', European Conference on Positive Psychology. Angers, France. 28 Jun1 Jul.

Devis-Rozental, C., Eccles, S., Mayer, M., and Jones, J. (2014) 'Developing socioemotional intelligence in first year students', Inspiring future generations embracing plurality and difference in higher education: Society for Research into Higher Education (SRHE) Annual Research Conference. Newport, Wales 10-12 December.

Dryden, G. and Vos, J. (1994) The learning revolution. Canada: Skills of Learning Publications.

Fayombo, G. A. (2012) 'Relating emotional intelligence to academic achievement amongst university students in Barbados', The International Journal of Emotional Education, 4(2), pp. 43-54.

Foster, E., Lawther, S. and McNeil, J. (2011) 'Learning developers supporting early student transition', in Hartley, P., Hilsdon, J., Keenan, C., Sinfield, S. and Verity, M. (eds.) Learning development in higher education. Basingstoke: Palgrave Macmillan pp. 79-90.

Gardner, H. E. (2000) Intelligence reframed: multiple intelligences for the 21st century. New York: Basic Books. 
Goleman, D. (1996) Emotional intelligence: why it can matter more than IQ. London: Arrow Books.

Goleman, D. (2007) Social intelligence:the new science of human relationships. London: Arrow Books.

Higher Education Academy, (2016) Student retention and success in higher education.

Available at: https://www.heacademy.ac.uk/workstreamsresearch/themes/retention-and-success (Accessed: 27 August 2016).

Hilsdon, J. (2011) 'What is learning development?', in Hartley, P., Hilsdon, J., Keenan, C., Sinfield, S. and Verity, M. (eds.) Learning development in higher education. Basingstoke: Palgrave Macmillan, pp. 11-27.

Holloway, I. and Brown, L. (2012) Essentials of a qualitative doctorate. California: Left Coast Press, Inc.

Hudson, L. and Ozanne, J. (1988) 'Alternative ways of seeking knowledge in consumer research', Journal of Consumer Research, 14(4), pp. 508-521. https://doi.org/10.1086/209132

Humphrey, N., Lendrum, A. and Wigelsworth, M. (2010) Social and emotional aspects of learning (SEAL) programme in secondary schools: national evaluation. Manchester: Department for Education (DFE-RR049). Available at: https://www.gov.uk/government/uploads/system/uploads/attachment data/file/1817 18/DFE-RR049.pdf (Accessed: 20 October 2017).

Jennings, P. A. and Greenberg, M. T. (2009) 'The prosocial classroom: teacher social and emotional competence in relation to student and classroom outcomes', Review of Educational Research, 79(1), pp. 491- 525. https://doi.org/10.3102/0034654308325693

Johnson, A. P. (2005) A short guide to action research. Boston: Allyn and Bacon. 
Lankshear, C. and Knobel, M. (2011) New literacies: everyday practices and social learning. Maidenhead: Open University Press.

Latsome, L. (2013) 'Socially intelligent intercultural education', Educational Research Journal (教育研究學報), 28(1/2), pp. 145-162. Available at:

http://hkier.fed.cuhk.edu.hk/journal/wp-content/uploads/2014/04/ERJ v28n1-2 145162.pdf (Accessed: 20 October 2017).

Liamputtong, P. (2011) Focus groups methodologies: principles and practice. London: Sage Publications Ltd.

Lincoln, Y. and Guba, E. (1985) Naturalistic Inquiry. London: Sage.

Low, G., Lomax, A., Jackson, M. and Nelson, D. (2004) 'Emotional intelligence: a new student development model', National Conference of the American College Personnel Association. Philadelphia, Pennsylvania. Available at: https://pdfs.semanticscholar.org/48be/fc9180883782e590fb0e0f28ffb0c0395402.pdf (Accessed: 9 November 2017).

Matters, H., Winter, J and Nowson, C. (2004) 'Enhancing learning for culturally and linguistically diverse (CALD) students', Focus on Health Professional Education, 6(1), pp. 26-36. Available at: http://dro.deakin.edu.au/eserv/DU:30002543/nowsonenhancinglearning-2004.pdf (Accessed: 9 November 2017).

Parker, J. D. and Duffy, J, M. (2005) Making successful transition during the first year of college: does emotional intelligence matter? Available at:

http://citeseerx.ist.psu.edu/viewdoc/download?doi=10.1.1.458.2733\&rep=rep1\&type $=$ pdf (Accessed: 9 November 2017).

Payton, J., Weissberg, R., Durlak, A., Dymnicki, A. B., Taylor, R, D., Schellinger, K. B. and Pachan, M. (2008) The positive impact of social and emotional learning for kindergarten to eighth-grade students: findings from three scientific reviews. Chicago: Collaborative for Academic, Social and Emotional Learning (CASEL). 
Available at: http://files.eric.ed.gov/fulltext/ED505370.pdf (Accessed: 20 October 2017).

Perera, H, N. and DiGiacomo, M. (2015) 'The role of trait emotional intelligence in academic performance during the university transition: an integrative model of mediation via social support, coping and adjustment', Personality and Individual Differences, 83, pp. 208-213. https://doi.org/10.1016/j.paid.2015.04.001

Qualter, P., Whiteley, H., Morley, A. and Dudiak, H. (2009) 'The role of emotional intelligence in the decision to persist with academic studies in HE', Research in Post-Compulsory Education, 14(3), pp. 219-231. http://dx.doi.org/10.1080/13596740903139255

Salovey, P. and Mayer, J. D. (1990) 'Emotional intelligence', Imagination, Cognition and Personality, 9(3), pp. 185-211. https://doi.org/10.2190/DUGG-P24E-52WK-6CDG

Seal, C. R., Naumann, S. E., Scott, A. N. and Royce-Davis, J. (2011) 'Social emotional development: a new model of student learning in higher education', Research in Higher Education Journal (Academic and Business Research Institute), 10, pp. 113. Available at: http://www.aabri.com/manuscripts/10672.pdf (Accessed: 20 October 2017).

Stewart, D. W., Shamdasani, P. N. and Rook, D. W. (2007) Focus groups: theory and practice. $2^{\text {nd }}$ edn. Thousand Oaks: Sage Publications.

Thorndike, E. L. (1920) 'Intelligence and its uses', Harper's Magazine, 140, pp. 227-235

Vygotsky, L. S. (1978) Mind in society: the development of higher psychological processes. USA: Harvard University Press.

\section{Author details}


Dr Camila Devis-Rozental is a Learning Development Academic at Bournemouth University. Her expertise is in Education and the role that emotions and social interactions can have on effective learning and teaching. She is also interested in the notion that enjoyment and achievement should be intrinsically linked within the classroom for successful learning.

Dr Sue Eccles is acting Deputy Head of the Centre for Excellence in Learning at Bournemouth University and has worked in HE since 1995. Her research is focused around the experiences of students as they transition into, through and out of Higher Education, the Widening Participation policy agenda and how this impacts on/influences practice, and supporting academics through effective leadership. She has experience of strategic management and leadership, as well as in-depth knowledge and understanding of education practice within HE.

Marian Mayer is a Learning Development Academic at Bournemouth University. She is currently completing a doctoral study "Understanding Habitus and Transformative Learning in Undergraduate Media Students" which, rather than focussing on the 'process' of transformation explores 'what' is transformed, and how that transformation occurs. Her study develops transformational learning and considers the potential for Bourdieu's concept of Habitus can be utilised as a theoretical and methodological tool to study the impact of transformational learning on undergraduate students. 